\title{
PERCEPTIONAL APPROACH IN SOCIAL-GEOGRAPHICAL RESEARCH OF THE URBAN SPACE (ON THE EXAMPLE OF LVIV)
}

\author{
Myroslava VLAKH, Iryna HUDZELYAK
}

Ivan Franko National University of Lviv, Ukraine
kafedra.Iviv@gmail.com

\begin{abstract}
The color perception and evaluation of the attitude of the student youth towards 20 territorial parts of Lviv urban space were analyzed. The importance of the studentification for the functional transformation of urban space was emphasized. A technique developed by the Swiss psychologist M. Lusher was used to research the color perception of urban space. An electronic poll of 205 students was conducted, the results of which were analyzed in three age categories. The study found a low coefficient of asymmetry in the responses and determined a minimum threshold for a unique interpretation of the "color" of the area. A mental map of the color perception of Lviv was performed, which distinguishes areas dominated by the perception of the same color, the combination of two colors, the indistinct distribution, as well as the positive, negative and uncertain attitude of students towards them. Warm colors (yellow, green, red) were found to relate mainly to the areas of study, dwelling, and the most frequent location of the students, as well as to the desired places of residence. Black and gray colors dominate in the perception of industrial and transport-industrial districts of Lviv, which received negative opinions. The results of the study can be used in the process of adaptive transformation (according to student needs) of Lviv urban space and in specificating the paradigm of its development. In particular, according to the poll, a large part of Lviv has negative or uncertain attitude, thus its further functional transformation must take into account the needs of student youth. Colored association with territorial parts of the city may also be used for creation of verbal urbal images and formulation of relevant geospatial metaphors.
\end{abstract}

Key words: urban space, Lviv, perceptual geography, studentification, color.

DOI: https://doi.org/10.17721/2413-7154/2019.82.50-56

UDC: [911.3:911.375](477.83-25):[910.2:159.937.22]

Received: December 16, 2019.

Revised: December 24, 2019.

Accepted: December 26, 2019.

\section{ПЕРЦЕПЦІЙНИЙ ПІДХІД У СУСПІЛЬНО-ГЕОГРАФІЧНИХ ДОСЛІДЖЕННЯХ МІСЬКОГО ПРОСТОРУ (НА МАТЕРІАЛАХ ЛЬВОВА)}

\author{
Мирослава ВЛАХ, Ірина ГУДЗЕЛЯК
}

\author{
Львівський національний університет імені Івана Франка, Україна \\ kafedra.lviv@gmail.com
}

\begin{abstract}
Анотація: Проаналізовано колористичну перцепцію та оцінне ставлення студентської молоді до 20-ти територіальних частин міського простору Львова. Підкреслено значення чинника студентифікації для функціональної трансформації міського простору. Для колористичного сприйняття міського простору використано методику, розроблену швейцарським психологом М. Люшером. Проведено електронне опитування 205-ти студентів, результати якого проаналізовані у трьох вікових когортах. Встановлено низький коефіцієнт асиметрії відповідей, а також визначено мінімальний поріг однозначного трактування "забарвлення" району. Виконано ментальну картосхему колористичного сприйняття міста Львова, яка виокремлює райони за домінуванням у сприйнятті одного кольору, поєднанням двох кольорів, нечітким розподілом, а також із позитивним, негативним та невизначеним ставленням студентів до них. 3'ясовано, що кольори теплої гами (жовтий, зелений, червоний) стосуються сприйняття переважно районів навчання, проживання і найчастішого перебування студентів, а також бажаних місць проживання. Чорна і сіра колористика домінує у сприйнятті промислових і транспортно-промислових районів Львова, які отримали негативну оцінку. Результати дослідження можуть бути використані у процесі адаптивної трансформації (відповідно до студентських потреб) міського простору Львова, в уточненні парадигми його розвитку.

Ключові слова: міський простір, Львів, перцепційна географія, студентифікація, колір.
\end{abstract}




\section{Актуальність дослідження}

Перцепційна географія - відносно молода конвергентна наука, сформована на стику соціальної географії і психології [14, с. 241]. Вона виникла у 1950-1960 pp. у рамках бігейвіористичної географії. Ïі предметна сфера зумовлена застосуванням теоретичних і методичних напрацювань психології у традиційних географічних дослідженнях. Це дає змогу на основі сенсорного сприйняття стимулів від довкілля отримувати відповідні перцепційні характеристики та враховувати ïx у процесі територіального планування та управління. Перцепційно-географічні дослідження особливо ефективні на локальному рівні через постійність і чітку територіальну диференційованість сенсорних впливів.

Низовими об'єктами перцепційногеографічного дослідження можуть бути поселення - місця значної концентрації населення, де й відбуваються усі види його життєдіяльності. Об'єктом дослідження є велике за людністю місто - Львів (724,7 тис. осіб станом на 1 січня 2019 р.). Оптимізація компонентно-функціональної і територіально-функціональної структури міста повинна відбуватися також 3 урахуванням сприйняття міського простору його мешканцями, зокрема студентською молоддю.

Перцепційно-географічні дослідження міст переважно відбуваються у контексті формування їхніх образів, створення відповідного іміджу i просування бренду. Урбоімагологія пройшла шлях від створення констатуючих образів на основі безпосереднього чуттєвого сприйняття міст до геообразотворення 3 урахуванням певних критеріїв, зокрема й прогностичного [13]. Правильно сформований позитивний образ міста є важливим інноваційним інструментом управління його соціально-економічним розвитком. Урбообраз, враховуючи унікальні, своєрідні особливості, сприяє підвищенню конкурентоспроможності міста через управління його ресурсами 3 максимальною ефективністю. Позитивний образ міста впливає на інвестиційні переваги, а також на його соціальну, культурну, політичну сфери.

Важливою є також перцепція окремих частин міського простору, виявлення їхньої сумісності/ несумісності з цілісним образом міста. Дослідники підкреслюють особливе значення вулиць, домінантних точок у створенні образів великих міст. У свідомості мешканців формується вулична модель міського простору [4]. Поет і співак Андрій Кузьменко (Кузьма Скрябін), наприклад, у пісні “То є Львів" за допомогою вдалих художніх прийомів відтворив образ окремих територіальних частин міста: "Левандівка пахне поїзами, мостами, переїздами i гострими словами”, "Ратуша скучає, шпилем небо дзюравить”, “Сихів в автобусі надихав, вікна запотіли від запахів неділі", "Площза Ринок спати не лягає, історії збирає і розповідає”, “сімка (трамвай. -

(C) Myroslava Vlakh, Iryna Hudzelyak
Ред.) вниз на Погулянкуповертає, дзеленькає сердито, бо все часу не має”, “а ще костел на Привокзальній”, “стара Пекарська, ... я нею нагулявся, як пари пропускав $і$ по Личакову хитався”. 3 таких образків і складається цілісний образ Львова - “старенького, мудрого, сивого дядька, вуйка гонорового”. Мовне осмислення міського простору стає важливим напрямком гуманітарно-географічних досліджень.

\section{Аналіз останніх публікацій}

Перцепційно-географічні дослідження в українській науці пов'язані з іменами К. Мезенцева $[8,9]$, Н. Мезенцевої [8], М. Гродзинського [5], М. Барановського, О. Барановської [1], О. Гнатюка, А. Мельничука [3] та ін. Вони присвячені сприйняттю регіонів України, ландшафтів, окремих міст, методиці бігейвіористичного прогнозування регіонального розвитку тощо. Суспільно-географічні дослідження особливостей колористичного сприйняття внутрішньоміського простору, відповідної оцінки та розроблення на цій основі напрямків його трансформації відсутні.

\section{Мета дослідження}

Мета дослідження полягала у виявленні та інтерпретації колористичної перцепції міського простору Львова, картографуванні оцінного ставлення студентської молоді до його окремих територіальних частин, а також у розробленні пропозицій щодо можливих напрямків адаптивної трансформації міського простору.

\section{Методика досліджень}

Для проведення дослідження використано метод анкетування. Електронна анкета, запропонована для студентів львівських вищих закладів освіти, налічувала вісім запитань. 3 них три запитання стосувалися особистості респондента (рік навчання, стать, місце здобуття попередньої освіти - Львів або іншемісце).Щетризапитаннястосувалися визначення районів проживання, частого перебування і бажаного проживання. Центральними в анкеті були запитання щодо кольоровідчуття окремих частин міського простору та визначення позитивного/негативного ставлення до них.

Для колористичного сприйняття міського простору застосовано методику, розроблену швейцарським психологом М. Люшером (1923-2017) [6]. Оригінальна методика для визначення психоемоційного стану людини враховує як функцію кольору (суб'єктивне ставлення респондента до кольору у момент дослідження), так і структуру кольору (об'єктивне знання про колір, його психологічний зміст). У проведеному дослідженні тест Люшера спрощено й апробовано відповідно до мети дослідження: емоційний стан кожного окремого респондента, його психофізичні, естетичні, художньо-образні особливості не бралися до уваги, аналізувалися лише переваги у виборі певного 
кольору усією когортою та окремо студентами першого, третього-шостого років навчання.

В електронному анкетуванні щодо колористичного сприйняття міста Львова та загальної оцінки його районів взяли участь 205 студентів переважно географічного факультету та інших факультетів Львівського національного університету імені Івана Франка та кількох інших закладів вищої освіти Львова. Лише 31 \% із них здобули попередню освіту в навчальних закладах Львова, 53 \% - студенти першого курсу. Отже, відповіді респондентів переважно відображають “перші” відчуття, ще не осмислені у процесі тривалішого перебування у місці дослідження.

3 метою недопущення прямолінійності у сприйнятті колористики міського простору, анкетування проводилися в університетських аудиторіях, а самі студенти не були попередньо про це поінформовані. Таким чином, вони могли відобразити просторові одиниці Львова не буквально, а крізь призму свого попереднього досвіду проживання у місті, тобто відповідно до особистої схеми апперцепції. За загальними результатами анкетування суб'єктивні впливи нівелюються і формується колективне сприйняття, яке ми пов'язуємо з особливостями певного простору. Колір стає ніби атрибутом дійсності. Груповий колористичний образ потребує своєї інтерпретації і може бути врахований у процесі функціональної трансформації території.

Для інтерпретації кольорів використано усталену у психології символіку. Зокрема, в українській культурі із синім кольором асоціюють спокій, порядок, безпеку, безкінечність, задоволення; зеленим - природу, життя, спокій, гармонію, молодість, упевненість; жовтим легкість, тепло, радість, оптимізм, відкритість; фіолетовим - холод, проблемність, таємничість; коричневим - конфліктність; чорним - темряву, депресію, невдоволення, страх; сірим-невиразність, скромність, повсякденність, старість, консерватизм, нерозкритість [10].

На першому етапі статистичного опрацювання отриманих результатів був обчислений коефіцієнт асиметрії відповідей усіх респондентів, що змогли визначитися 3 колірною асоціацією просторових елементів Львова - 0,18. Враховуючи низьке значення коефіцієнта асиметрії (при його наближенні до нуля, “розкиданість” думок зростає), визначено мінімальний поріг однозначного (домінуючого) трактування “забарвлення” району - 39 респондентів. Це показник, що пропорційний максимальному відсоткові повторюваності відповідей в одній із досліджуваних когорт.

Перцепційна оцінка стосувалася 20-ти окремих частин міського простору, визначених за головними транспортними артеріями міста, а також усталеними назвами його окремих частин (Знесіння, Левандівка, Майорівка, Новий Львів, Підзамче, Привокзальна, Рясне, Сихів, Центр, вулиці Б. Хмельницького, Городоцька, Зелена, Кульпарківська, Личаківська, Люблінська - Виговського, Наукова - Княгині Ольги,
Стрийська,

Чорновола

Мазепи,

Чупринки - Коновальця, Шевченка). Опитування охоплювало увесь міський простір [7].

Для статистичного опрацювання отриманого масиву даних використано програму Microsoft Excel, iз застосуванням картографічного методу побудовано ментальну карту “Сприйняття студентами міського простору Львова”.

\section{Виклад основного матеріалу}

Львів - регіональний центр західної частини України і духовна столиця держави, що має тривалу історію свого розвитку (перша писемна згадка датується 1256 роком). Природні, історичні та соціально-економічні особливості міста зумовили його неоднорідну територіально-функціональну організацію: наявність історичного центру, середмістя XIX - початку XX ст., житлових районів совєтської забудови, депресивних промислових зон.

Міські стратегії, які розроблялися на перспективу й стосувалися як окремих міських мікрорайонів, так і міста загалом, або й міської агломерації, мали на меті удосконалення просторової структури для економічного зростання, забезпечення вищої якості життя людей та збереження екологічної безпеки, виходячи 3 фінансових можливостей міста [2]. Проте, майже усі містопланувальні ідеї не брали до уваги студентство - значну складову львівської громади. На початку 2019 р. у 30-ти закладах вищої освіти Львова навчалися понад 100 тис. студентів, “студентське навантаження” становило 138 осіб / 1000 осіб постійного населення. Ще 9 тис. осіб навчались у середніх спеціальних закладах освіти.

Вплив студентства на міську трансформацію, зокрема у контексті дослідження джентрифікації, вперше показав А. Варде (A. Warde). Науковець запропонував термін студентифікація (англ. studentification) та сформулював його означення [15]. У західній науці появилася низка публікацій, присвячених географічному, соціологічному та економічному аналізові впливу студентства на міський простір окремих освітніх центрів Європи та Північної Америки. Підтверджуючи важливість таких досліджень, 2002 року термін студентифікація був занесений до топ-100 нових слів, який укладає ВBC $[12$, с. 74]. Концептуальне осмислення студентифікації здійснив Д. Сміт (D. Smith). Автор науково обгрунтував чотири аспекти впливу студентифікації на міську трансформацію: економічний, соціальний, культурний та фізичний (просторовий, інфраструктурний) [12, с. 75-76]. Географічний аналіз студентифікації в одному 3 британських освітніх центрів - Брайтоні - здійснила Дж. Сейдж (J. Sage) [11]. В Україні дослідження сприйняття міського простору студентами на прикладі Луганська здійснив В. Злотін [16].

Результати анкетування щодо асоціації окремих частин Львова 3 кольоровою гамою відображають просторову диференціацію міста. У табл. 1 показано райони 3 домінуванням певного кольору/кольорів, а також райони, де жоден із 
кольорів не набрав мінімального порогу відповідей, а сприйняття студентами розподілилося між двома найпоширенішими варіантами кольорів або оцінок (позначено курсивом).

Проведене дослідження виявило переважання у сприйнятті студентами більшості частин міського простору через “позитивні" кольори теплої гами. Найчастіше трапляються жовтий колір та поєднання жовтим.

Чіткі колористичні асоціації та позитивну оцінку мають Центр, Майорівка, Новий Львів, Шевченка, Чорновола - Мазепи, Зелена, Знесіння, Стрийська. Це легко ідентифіковані частини Львова з головними транспортними артеріями, міжміськими автостанціями (“дорога додому”), місцями проживання студентів (“рідний дім”) або парками (“райські місця”). Помітно, що зелений і жовтий кольори студенти сприймають буквально, як зелену зону й жовту забудову відповідно.

у контексті перцепційно-колористичної характеристики підтвердилася проблемність промислових i транспортно-промислових районів (Левандівка, Привокзальна, Городоцька, Підзамче, Б. Хмельницького) 3 домінуванням у їхньому

сприйнятті сірого та чорного кольорів та переважно негативною оцінкою. Вулиця Кульпарківська також оцінюється студентами негативно попри нову гармонійну забудову, благоустрій і наявність прямого тролейбусного сполучення з Центром: на і1ї сприйняття впливає розташування там психіатричної лікарні.

Нечіткий розподіл кольорів за позитивної оцінки отримали малознані студентам периферійні райони 3 новою забудовою, аеропортом, новими офісними центрами - Люблінська - Виговського (червоний, жовтий, сірий кольори) і Наукова - Княгині Ольги (червоний, синій, жовтий кольори). Найбільший за людністю мікрорайон Сихів (жовтий, червоний, зелений кольори), який протягом останніх років формується як новий привабливий багатофункціональний внутрішньоміський вузол, важко піддається ідентифікації. Не змогли студенти визначитися з оцінним ставленням до елітного району Чупринки - Коновальця (червоний, жовтий, сірий кольори) з малоповерховою змішаного садибного i багатоквартирного типу забудовою у середмісті, де відсутні привабливі для молоді торговельні та розважальні заклади.

Таблиияя 1

Перцепційна оцінка територіальних частин м. Львова

\begin{tabular}{|c|c|c|c|}
\hline \multirow{2}{*}{$\begin{array}{l}\text { Домінуючі кольори } \\
\text { (\% від загальної } \\
\text { кількості відповідей) }\end{array}$} & \multicolumn{2}{|c|}{ Домінуюча оцінка } & \multirow[b]{2}{*}{ Оцінка невизначена } \\
\hline & позитивна & негативна & \\
\hline Жовтий (18) & $\begin{array}{c}\text { Центр } \\
\text { Майорівка } \\
\text { Новий Львів } \\
\text { Шевченка } \\
\text { Б. Хмельницького } \\
\text { Городоцька } \\
\text { Личаківська } \\
\text { Підзамче }\end{array}$ & & \\
\hline Червоний (16) & $\begin{array}{c}\text { Чорновола - Мазепи } \\
\text { Личаківська }\end{array}$ & & \\
\hline Зелений (15) & $\begin{array}{c}\text { Зелена } \\
\text { Знесіння } \\
\text { Стрийська }\end{array}$ & & \\
\hline Сірий (14) & $\begin{array}{l}\text { Привокзальна } \\
\text { Б. Хмельницького } \\
\text { Городоцьька } \\
\text { Підзамче }\end{array}$ & Привокзальна & \\
\hline \multicolumn{4}{|l|}{ Синій (12) } \\
\hline \multicolumn{4}{|l|}{ Фіолетовий (9) } \\
\hline Чорний (8) & & Левандівка & \\
\hline \multicolumn{4}{|l|}{ Відсутня оцінка (8) } \\
\hline Розподіл нечіткий & $\begin{array}{c}\text { Любінська - Виговського } \\
\text { Наукова - Княгині Ольги } \\
\text { Сихів } \\
\text { Чупринки - Коновальия } \\
\text { Рясне }\end{array}$ & Кульпарківська & $\begin{array}{c}\text { Чупринки - Коновальия } \\
\text { Рясне }\end{array}$ \\
\hline
\end{tabular}




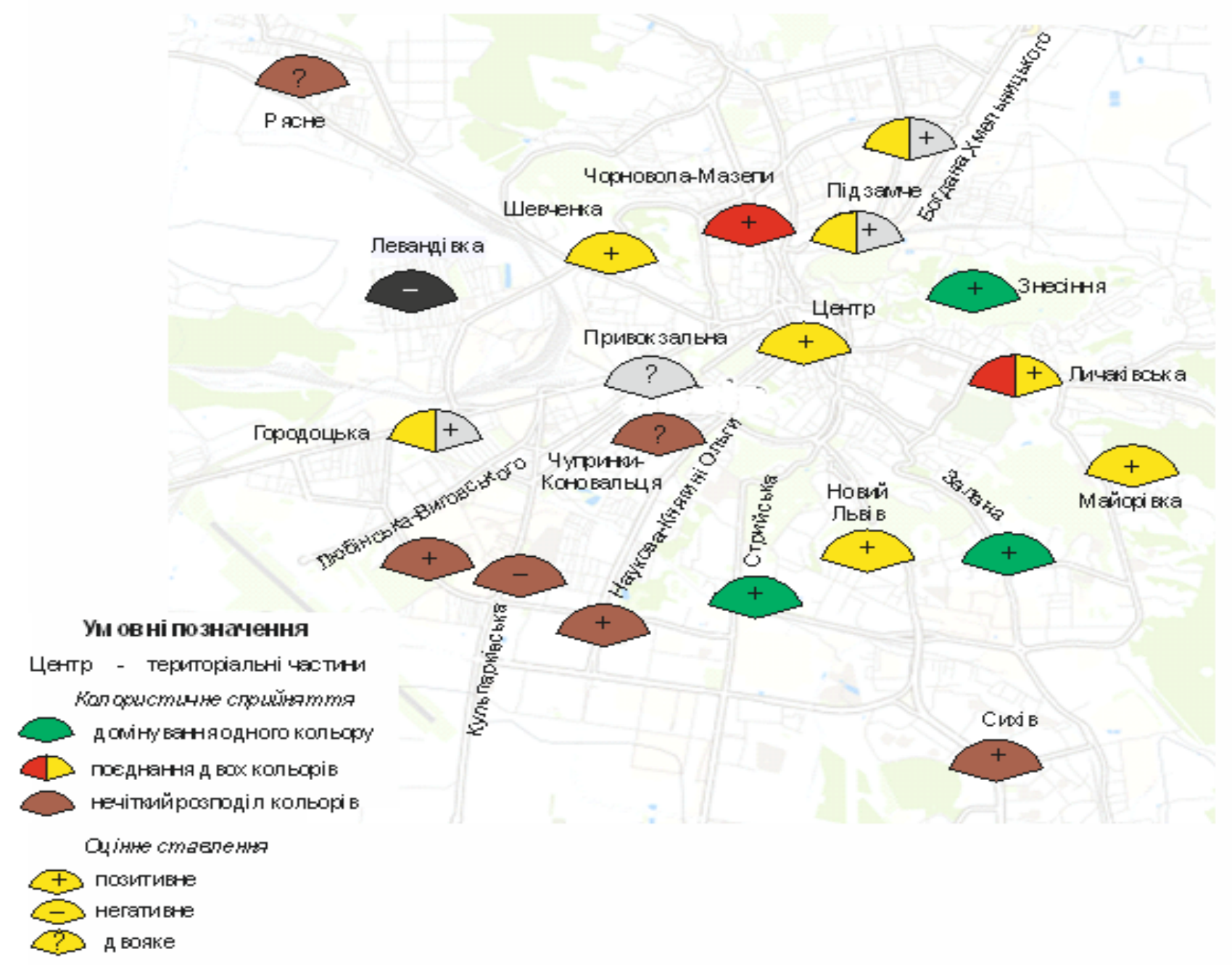

Рис. 1. Сприйняття студентами міського простору Львова

Двояку оцінку отримав периферійний i найгірше транспортно пов'язаний із центром міста район Рясне (червоний, жовтий, зелений кольори), який раніше виконував промислові функції, мав компактну багатоповерхову забудову для працівників розташованих тут підприємств. Зараз тут провадиться активне житлове будівництво найдешевших у Львові квартир, однак соціальна інфраструктура практично не удосконалюється.

Очікуваними виявилися результати щодо вибору бажаного місця проживання у Львові. Характерно, що, постійно проживаючи в районі студентських гуртожитків (Майорівка, 19 \%), на Личаківській, яка з'єднує студентське містечко і Центр (13\%), Центрі (9 \%) і в спальному районі Сихів (8\%), понад $60 \%$ опитаних обрали як місце свого бажаного проживання Центр і центральний Галицький район, а також Франківський, де саме розміщений Новий Світ - район вулиць Чупринки - Коновальця, на третьому місці - Сихів (9 \%).

Привабливість Центру зумовлена насамперед концентрацією тут освітніх закладів, соціально- культурних об'єктів. Це опосередковано засвідчує також недостатній розвиток $\mathrm{i}$ транспортну недоступність (ізольованість) периферійних районів. На цьому фоні вигідно вирізняється Сихів - район житлової забудови 70-80 pр. XX ст., куди в останні роки спрямовувалися суттєві інвестиції (налагодження трамвайного сполучення з Центром, будівництво торговельних центрів, об'єктів спортивної інфраструктури, закладення парку, упорядкування міжбудинкових просторів). Переваги, надані Центрові у виборі бажаного місця проживання, виявляють гостроту диференціації міського простору. Незаперечно, що гіпертрофований розвиток Центру - ознака міського життя країн, що розвиваються.

Очікувано іншим виявилося ставлення до Центру студентів різних років навчання. Так, серед першокурсників 49 \% опитаних бажали б проживати у Центрі, ще $11 \%$ - на Сихові. Серед студентів 3-6 років навчання тих, хто хоче проживати у Центрі, було лише $23 \%$, у Франківському районі - $15 \%$. Молоді люди 3 
певним “міським” досвідом краще усвідомлюють проблеми центрів старих міст - транспортні корки і транспортну втому, забруднене повітря, неякісний житловий фонд, які не нівелюють певні “молодіжні” переваги, зокрема велика концентрація закладів дозвілля і потенційних місць праці (ресторани, бари, нічні клуби, готелі та інші сервісні установи). Загалом, усвідомлене позитивне ставлення до Центру мають 94\% старшокурсників й трохи менше - $87 \%$ першокурсників.

Образ міста Львова представлено за допомогою ментальної карти, якає відображенням у свідомості студентів міського простору (рис. 1). Зокрема, виявлено три типи територіальних частин Львова за оцінним ставленням студентів: чітко визначені 3 позитивним ставленням (Центр, Майорівка, Новий Львів, Шевченка, Чорновола - Мазепи, Зелена, Знесіння, Стрийська, Любінська Виговського, Наукова - Княгині Ольги, Сихів), чітко визначені з негативним ставленням (Левандівка, Кульпарківська), невизначеним ставленням (Б. Хмельницького, Городоцька, Личаківська, Підзамче, Привокзальна, Чупринки - Коновальця, Рясне). Оскільки значна частина території Львова належить до другого і третього типів сприйняття, їхня подальша функціональна трансформація повинна відбуватися 3 урахуванням потреб студентської молоді.

\section{Висновки}

Проведене дослідження дало змогу проаналізувати сприйняття та виявити ставлення студентів до різних частин міського простору Львова. На основі колористичної апперцепції та семантики колірної гами визначено комфортні і привабливі райони, які асоціюються 3 теплою гамою кольорів, та проблемні й непривабливі для молоді райони, що були позначені ними холодною гамою кольорів.

За результатами соціологічного опитування можна виявити ментальну диференціацію міського простору, оцінити ймовірну траєкторію розвитку окремих районів міста, тенденції формування внутрішньоміських вузлів. Апробована методика може використовуватись як додаткова при кількісному оцінюванні якості життя в місті, для визначення тих міських просторів, які потребують особливої цілеспрямованої стратегії, конкретних планувальних та управлінських рішень (адаптивна до потреб студентської молоді трансформація, реструктуризація, реновація, джентрифікація, ексклюзивізація тощо).

Колористична асоціація окремих частин міста може бути використана також при створенні вербальних урбообразів, формулюванні відповідних геопросторових метафор. Це важливо в умовах будівництва нових житлових комплексів iз нехарактерними для Львова назвами (“Велика Британія", “Америка", "Парус" тощо).

\section{References:}

1. Baranovskyi M, Baranovska $\mathrm{O}$. Bìhevìorističnij pìdhìd u doslìdžennì regìonal'noï depresivnostì [A behavioral approach in the study of regional depressivity]. - Access mode: http://ekhsuir.kspu.edu/ bitstream/123456789/5404/1/M.\%20.\%20Baranovsky\%2C\%20O.\%20V.\%20Baranovska.pdf. (In Ukrainian).

2. Lviv Master Plan for 2025. Access mode: www.city-adm.lviv.ua. (In Ukrainian).

3. Gnatiuk O., Melnychuk A. İdentičnìst' viznačnih lokacìj mìsta Vìnnicì [Place identity of selected locations in the city of Vinnytsia]. Scientific Bulletin of the Kherson State University. Series: Geographical Sciences, 2019, No. 11, p. 16-24. (In Ukrainian).

4. Hold D. Psihologiâ i geografiâ: osnovy povedenčeskoj geografii [Psychology and Geography: Foundations of Behavioral Geography]. Moscow, 1990, 304 p. (In Russian).

5. Hrodzynskyi M. D. Piznannâ landšaftu: misce i prostìr [Knowledge of landscape: place and space]. Kyiv, 2005, 503 p. (In Ukrainian).

6. Luscher M. The Luscher Color Test. - New York: Pocket Books, 1971, 224 p.

7. Lviv. L'vìv. Kompleksnij atlas [Lviv. Complex atlas]. Kyiv, 2012, 192 p. (In Ukrainian).

8. Mezentseva N., Mezentsev K. Percepcìjnì portreti regìonìv Ukraïni [Perceptual portraits of Ukrainian regions]. Regional'nì problemi Ukraïni: geografičnij analiz ta pošuk šlâhìv virišennâ [Regional problems of Ukraine: geographical analysis and search for solutions]. 2005, pp. 208-213. (In Ukrainian).

9. Mezentsev K. Metodika bìhevìorističnogo prognozuvannâ regìonal'nogo rozvitku [Methods of Behavioral Prediction of Regional Development]. Ekonomichna ta sotsialna geografiya [Economic and social geography], 2004, vol. 54, pp. 17-24. (In Ukrainian).

10. Pechenyuk T. Kol'oroznavstvo [Color science]. Kyiv, 2009, 191 p. (In Ukrainian).

11. Sage J. The micro-geographies of studentification in Brighton and Hove. 2010. Access mode: https:/cris. brighton.ac.uk/ws/portalfiles/portal/4756101/SAGE+thesis+CORRECTED_static_Redacted.pdf

12. Smith D. "Studentification": the gentrification factory? Gentrification in a Global Context. The new urban colonialism. London, New York, 2005.

13. Vlakh M., Koropetska T. Urboobrazi âk naprâm regìonal'nogo turističnogo menedžmentu / na materìalah L'vìvs'koï oblastì [Urban image as a direction of regional tourism management (on the materials of the Lviv region)].

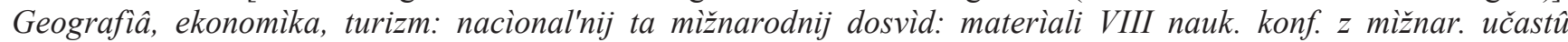
[Geography, economics, tourism: national and international experience: materials of VIII conference with the 
international participation]. Lviv, 2014. pp. 151-155. (In Ukrainian).

14. Vlakh M., Kotyk L. Teorià ì metodologiâ geografičnoï nauki: navč. posibnik [Theory and methodology of geographical science]. Lviv, 2019, 334 p. (In Ukrainian).

15. Warde A. Gentrification as consumption: issues of class and gender [Gentrification as consumption: issues of class and gender]. Environment and Planning D, 1991, Vol. 9, pp. 223-232.

16. Zlotyn V. Mental'naâ karta Luganska: obraz goroda v soznanii studentov [Mental map of Luhansk: the image of the city in the minds of students]. Visnik ONU im. İ. İ. Mečnikova. Sociologîa ì političnì nauki [Visnyk of Mechnikov Odesa National University. Sociology and political science], 2013, vol 2 (18), part 1, pp. 267-273. (In Russian).

\section{Список використаних джерел:}

1. Барановський М. О. Біхевіористичний підхід у дослідженні регіональної депресивності / М. О. Барановський, О. В. Барановська. [Електронний ресурс]. - Режим доступу: http://ekhsuir.kspu.edu/ bitstream/123456789/5404/1/М.\%20О.\%20Барановський\%2С\%200.\%20В.\%20Барановська.pdf.

2. Генеральний план розвитку м. Львова до 2025 р. [Електронний ресурc]. - Режим доступу: www.cityadm.lviv.u

3. Гнатюк О. М. Ідентичність визначних локацій міста Вінниці / О. М. Гнатюк, А. Л. Мельничук // Науковий вісник Херсонського державного університету. Серія: Географічні науки. - 2019. - № 11. - С. 16-24.

4. Голд Дж. Психология и география: Основы поведенческой географии. - [пер. с англ.; авт. предис. С. В. Федулов]. - М.: Прогресс, 1990. - 304 с.

5. Гродзинський М. Д. Пізнання ландшафту: місце і простір: монографія / М.Д. Гродзинський. - У 2-х т. - К.: Видав.-поліграф центр Київський університет, 2005. - Т. 2. - 503 с.

6. Luscher M. The Lyucher Color Test / M. Luscher. - New York: Pocket Books, 1971. - 224 p.

7. Львів. Комплексний атлас. - [ред. О. Шаблій]. - К.: Картографія, 2012. - 192 с.

8. Мезенцева Н. І. Перцепційні портрети регіонів України / Н. І. Мезенцева, К. В. Мезенцев / Регіональні проблеми України: географічний аналіз та пошук шляхів вирішення. - Херсон, 2005. - С. 208-213.

9. Мезенцев К. В. Методика біхевіористичного прогнозування регіонального розвитку / К. В. Мезенцев // Економічна і соціальна географія. - 2004. - Вип. 54. - С. 17-24. $-191 \mathrm{c}$

10. Печенюк Т. Кольорознавство: підручник для студ. вищ. навч. закл. / Т. Печенюк. - Київ: Грані-Т, 2009.

11. Sage J. The micro-geographies of studentification in Brighton and Hove J. Sage // PhD thesis, 2010 [Електронний pecypc]. - Режим доступу: https://cris.brighton.ac.uk/ws/portalfiles/portal/4756101/ SAGE+thesis+CORRECTED_static_Redacted.pdf

12. Smith D. "Studentification": the gentrification factory? / D. Smith // Gentrification in a Global Context. The new urban colonialism. - [Ed. by R. Atkinson, G. Bridge]. - London, New York, 2005. - P. 73-90.

13. Влах М. Р. Урбообрази як напрям регіонального туристичного менеджменту / на матеріалах Львівської області // М. Р. Влах, Т. О. Коропецька // Географія, економіка, туризм: національний та міжнародний досвід: матеріали VIII наук. конф. $з$ міжнар. участю. - Львів, 2014. - С. 151-155.

14. Влах М. Теорія і методологія географічної науки: навч. посібник / М. Влах, Л. Котик. - Львів: ЛНУ, 2019. - $334 \mathrm{c}$.

15. Warde A. Gentrification as consumption: issues of class and gender / A. Warde // Environment and Planning D. - 1991. - Vol. 9. - P. 223-232.

16. Злотин В. Я. Ментальная карта Луганска: образ города в сознании студентов / В. Я. Злотин // Вісник ОНУ ім. І. І. Мечникова. Соціологія і політичні науки. - 2013. - Т. 18. - Вип. 2 (18). - Ч. 1. - C. 267-273. 